\title{
Can we reestablish a self-sustaining population? A case study on reintroduced Crested Ibis with population viability analysis
}

\author{
Yashuai Zhang ${ }^{1}$, Fang Wang ${ }^{1}$, Zhenxia Cui ${ }^{1}$, Min Li ${ }^{1}$, Xia Li $^{2}$, Xinping Ye ${ }^{1 *}$ and Xiaoping Yu ${ }^{1 *}$ (1)
}

\begin{abstract}
Background: One of the most challenging tasks in wildlife conservation and management is clarifying which and how external and intrinsic factors influence wildlife demography and long-term viability. The wild population of the Crested Ibis (Nipponia nippon) has recovered to approximately 4400, and several reintroduction programs have been carried out in China, Japan and Korea. Population viability analysis on this endangered species has been limited to the wild population, showing that the long-term population growth is restricted by the carrying capacity and inbreeding. However, gaps in knowledge of the viability of the reintroduced population and its drivers in the release environment impede the identification of the most effective population-level priorities for aiding in species recovery.

Methods: The field monitoring data were collected from a reintroduced Crested Ibis population in Ningshan, China from 2007 to 2018. An individual-based VORTEX model (Version 10.3.5.0) was used to predict the future viability of the reintroduced population by incorporating adaptive patterns of ibis movement in relation to catastrophe frequency, mortality and sex ratio.

Results: The reintroduced population in Ningshan County is unlikely to go extinct in the next 50 years. The population size was estimated to be 367 , and the population genetic diversity was estimated to be 0.97 . Sensitivity analysis showed that population size and extinction probability were dependent on the carrying capacity and sex ratio. The carrying capacity is the main factor accounting for the population size and genetic diversity, while the sex ratio is the primary factor responsible for the population growth trend.

Conclusions: A viable population of the Crested Ibis can be established according to population viability analysis. Based on our results, conservation management should prioritize a balanced sex ratio, high-quality habitat and low mortality.
\end{abstract}

Keywords: Carrying capacity, Nipponia nippon, Population viability analysis, Reintroduction, Sex ratio, VORTEX model

\section{Background}

Reintroduction aims to establish a viable population of the focal species within its indigenous range (IUCN/SSC 1998,2013). However, any reintroduction projects may fail to establish populations owing to either external or intrinsic factors that influence wildlife demography and

\footnotetext{
*Correspondence: yexinping@snnu.edu.cn; yuxp64@163.com

${ }^{1}$ College of Life Sciences, Shaanxi Normal University, Xi'an 710119, China

Full list of author information is available at the end of the article
}

long-term viability in different establishment phases (Armstrong and Seddon 2008; Robert et al. 2015). In particular, small and isolated populations are more at risk of extinction by the additional threats of chance events, such as demographic, environmental, genetic stochasticities, and catastrophic events. In these situations, population viability analysis (PVA), as an effective tool to assess the fates of populations under various scenarios of the deterministic forces and chance events, has been widely used in conservation biology for many endangered mammals 
and birds (Song 1996; Brook et al. 2000; Perkins et al. 2008; Hernandez-Camacho and Trites 2018; Kimanzi 2018; Brook et al. 2019; Blazquez et al. 2020; Fryxell et al. 2020; He et al. 2020). Specifically, PVA can provide some information about population dynamics, such as population size, extinction probability and genetic diversity change. For example, the viability of a reintroduced Bearded Vulture (Gypaetus barbatus) population was mainly affected by mortality and artificial supplementary release (Bustamante 1996). The current population of the Oriental White Stork (Ciconia boyciana) has a 12.5\% extinction probability in the next 100 years. Additionally, nestling mortality and the proportion of adult females involved in reproduction greatly impact population growth (Sung et al. 2012). The PVA results of the Western Lowland Gorillas (Gorilla gorilla gorilla) suggested that the reintroduced gorilla populations have a reasonable chance of persistence over 200 years, but the reinforcement of the populations could significantly improve probabilities of population persistence and retention of genetic diversity (King et al. 2014). Simulation results of PVA of the Sharp-tailed Grouse (Tympanuchus phasianellus) showed that, in a fixed scenario, improvement of habitat quality could facilitate the establishment of a minimum viable population by increasing fecundity and wintering survival (Milligan et al. 2018).

In the case of the Crested Ibis (Nipponia nippon) whose population once was thought to be extirpated (Archibald et al. 1980), its wild population has recovered to approximately 4400 (Shaanxi Hanzhong Crested Ibis National Nature Reserve, unpublished data) and several reintroduction programs have been successively carried out in China (Yu et al. 2015), Japan (Nagata and Yamagishi 2016) and Korea (Yoon and Choi 2018). However, up to date, population viability analysis on the endangered species has been limited to the wild population, showing a probability of extinction of $19.7 \%$ by 2097 ; long-term population growth is restricted by the carrying capacity and inbreeding, as it is more sensitive to catastrophes and habitat conditions (Li and Li 1998). A reconstructed PVA model predicted that the wild population would not go extinct in the next 50 years and revealed that population growth is significantly affected by the carrying capacity (Li 2013). Differences in the parameters used in the two PVA models led to variable prediction results.

Since the first reintroduction of the Crested Ibis in Ningshan, Shaanxi, China (Yu et al. 2009), new pair formations have continued to occur, and the number of fledglings and the distribution range has continued to increase. More recently, the population has survived the establishment stage, with high post-release dispersal and low survival, and it is now considered to be at the persistence stage (Huo et al. 2014; Yu et al. 2015; Dong et al. 2018). A recent study on the survival showed that the number and the range of the reintroduced population gradually increased without further releases (Li et al. 2018). Moreover, stochastic estimations of the population growth rate and population size simulated from an age-classified Leslie matrix indicated that the reintroduced population is likely to be at regulation phase over the next 25 years (Wang et al. 2017). However, gaps in knowledge of the viability of this population and its drivers in the release environment impede the identification of the most effective population-level priorities for aiding in species recovery. Here, we used a VORTEX model to simulate how the future dynamics of the population in the next 50 years to determine the key factors affecting its survival through sensitivity analysis. The process we used can serve as an example for developing a framework of conservation priorities on the population level.

\section{Methods \\ Study area}

The fieldwork was conducted in Ningshan County ( $33^{\circ} 07^{\prime} 09^{\prime \prime}-33^{\circ} 50^{\prime} 32^{\prime \prime} \mathrm{N}, 108^{\circ} 02^{\prime} 15^{\prime \prime}-108^{\circ} 56^{\prime} 44^{\prime \prime} \mathrm{E}$ ) of Shaanxi Province, which is located on the southern slope of the Qinling Mountains, China. The county is an important transportation hub connecting the Weihe Valley with the Sichuan-Chongqing region. Natural conditions of the study area have been reported in detail elsewhere (Yu et al. 2015). Most individuals of the reintroduced population were found in the middle reaches of the Changan River, one of the tributaries of the Hanjiang River (Li et al. 2018).

\section{Study population}

A total of 56 captive-bred individuals (27 females, 29 males) from two captive Crested Ibis populations were released to the wild from 2007 to 2011 (Yu et al. 2015). In addition, five individuals from the wild population in Yang County immigrated to Ningshan County through natural dispersal. By the end of the breeding season in 2020, a total of 220 offspring have fledged in Ningshan County. All released individuals and more than 95\% of the wild-born fledglings were marked with colored alphanumeric plastic bands (provided by the National Bird Banding Center of China) for field identification of their age and sex (Yu et al. 2015). Prior to release, eleven individuals were equipped with lightweight radio transmitters (model RI-2D; frequency 216.368-216.691 MHz; battery life $\sim 18$ months; Holohil Systems, Carp, Ontario, Canada) and two ibises with GPS trackers (Hunan Global Messenger Technology Co., Ltd., HQBG2512S) to monitor their subsequent fates. 


\section{Population modeling}

A VORTEX model (Version 10.3.5.0) for PVA, specific to vertebrates with a long lifespan and low fecundity (Miller and Lacy 2005), was used to predict dynamics of small populations as well as the future probability of population extinction. The PVA model has the potential to simulate the fates of each individual and gene flows among generations based on various random variables such as demographic, environmental, catastrophic and stochastic genetic events (Lacy 1993).

The demographic parameters in the VORTEX model were estimated based on the monitoring data of reintroduced Crested Ibis population from 2007 to 2018 (Table 1), and the model was used to simulate population dynamics over the next 50 years after 2018 to estimate the influencing parameters by the standard sensitivity index $\left(S_{x}\right)$ (Lacy 1993; Mccarthy 1995; Reed et al. 1998; Akcakaya and Sjögren-Gulve 2000; Morris and Doak 2002).

The current populations of the Crested Ibis including wild, captive and reintroduced populations were derived from seven individuals approximately 40 years ago, so each of them is an inbred population (Li et al. 2014; Feng et al. 2019; Fu et al. 2019). However, the Crested Ibis has survived the negative effect of inbreeding depression, and its distribution range and population size progressively expanded. It may be that the protracted inbreeding history has facilitated the purging of deleterious recessive alleles (Zhu et al. 2018). And gene mutation and natural selection can also eliminate the harmful recessive genes (Byers and Waller 1999; Keller and Waller 2002). The previous study on the wild Crested Ibis population showed that inbreeding has no significant impact on population growth (Li 2013). Therefore we assumed that the lethal equivalent value to zero for each diploid in the target population. The study population had a balanced sex ratio (1:1) in the initial population completely composed of captive-bred individuals, as well as the current population including released ibises and wild-born individuals. Population extinction was defined as all individuals of one sex are disappeared.

We assumed that Crested Ibis would be densitydependent, given that it is a territorial bird with limited nesting sites and food sources. Thus, the formula used in the VORTEX model was:

$$
P(N)=\left(P(0)-\left[(P(0)-P(K))\left(\frac{N}{K}\right)^{B}\right]\right) \frac{N}{N+A},
$$

in which $P(N)$ is the percentage of adult female breeders when the population size is $N ; P(K)$ is the percentage of adult female breeders at carrying capacity $(K) ; A$ is Allee parameter, which accounts for the decrease in the proportion of female breeders at low densities because of the increased difficulty of finding a mate at low population densities; And $P(0)$ is the percentage of adult female breeders at low densities when there is no Allee effect. The previous study revealed that there has a weak Allee effect (Chen 2018) and a positive annual growth rate in the target population (Wang et al. 2017), therefore we assumed the parameter $A$ to be zero. From 2007 to 2012, the focal ibis population, with a small size, was at the establishment stage (Additional file 1: Table S1), therefore we set $P(0)$ to 35.70 . For the territorial Crested Ibis with limited nesting sites and food sources, there will be intense intraspecific competition when the population size is close to the carrying capacity which may affect the number of female breeders in the population due to the limited availability resources (Henle et al. 2004). Thus, we assumed an ideal value of $P(K)$ is $50 \%$. The parameter $B$ was set to 2 , which means that $P(N)$ is a quadratic function of $N$. This function was commonly used to simulate the growth of a population with density dependence (Ralls et al. 1988).

Two types of catastrophes faced by our study population are floods and spring cold weather. Floods will inundate paddy fields, which will seriously affect Crested Ibis foraging, and the spring cold weather will threaten the chicks and reduce the food abundance. Based on meteorological data and reports of Ningshan County, the frequency of flood and spring cold weather are approximately $14 \%$ and $15 \%$, respectively. The effect of catastrophes on the reproduction and survival of Crested Ibis in Ningshan is unclear, so we assumed that $90 \%$ of the individuals survived a catastrophe and of those that survived, reproduction was reduced by $10 \%$ in the year of the catastrophes. Due to the wide range of Crested Ibis activities and understrength monitoring personnel, there is no detailed mortality data of Crested Ibis in Ningshan County at present. We used the survival of adults, subadults, and chicks to calculate the maximum mortality, and survival was $0.941,0.849$, and 0.549 , respectively (Wang 2015). Therefore, the maximum mortality of adults, subadults, and chicks was roughly estimated to be $5.9 \%, 15.1 \%$ and $45.1 \%$, respectively. To measure the impact of catastrophes on the population, we increased or reduced the frequency of catastrophes by $10 \%$ and $50 \%$ from the original baseline value. In the same way, the mortality rate of each age class was increased or decreased by $10 \%$, to measure the impact of the mortality on the population.

In a previous study, the total area of suitable habitats in Ningshan County was estimated to be $167.36 \mathrm{~km}^{2}$ using MaxEnt model (Wei 2020). The wild Crested Ibis population growth in the core nesting range may have been experiencing the suppression from the 
Table 1 Parameters of the VORTEX model used to simulate Crested Ibis population growth

\begin{tabular}{|c|c|c|}
\hline Variable & Explanation or notes & Default values \\
\hline \# of iterations & \# of times the simulation is run & 500 \\
\hline \# of years & \# of years the population is modeled & $50(2019-2068)$ \\
\hline Extinction definition & How extinction is defined in the model & Only one sex remains \\
\hline \# of populations & \# of populations to be modeled & 1 \\
\hline Inbreeding depression & The level and effect of inbreeding depression & Yes \\
\hline Lethal equivalents & The severity of inbreeding depression & 0 \\
\hline EV concordance of reproduction and survival & $\begin{array}{l}\text { The concordance between reproduction and survival } \\
\text { in different populations }\end{array}$ & Not applicable_-only 1 population modeled \\
\hline Dispersal rate & The rate of dispersal between populations & Not applicable_-only 1 population modeled \\
\hline Reproductive system & The mating system & Monogamy (Zhai et al. 1994) \\
\hline Age at 1 st reproduction in females & Age at which females begin breeding & 2 (Zhai et al. 1994) \\
\hline Age at 1 st reproduction in males & Age at which males begin breeding & 2 (Zhai et al. 1994) \\
\hline Maximum age at reproduction & Age of females/males when breeding ceases & 15 (Yu et al. 2007) \\
\hline Maximum \# of progeny produced/year & $\begin{array}{l}\text { Maximum \# of offspring produced by females each } \\
\text { year }\end{array}$ & 5 (Zhai et al. 2001) \\
\hline Sex ratio at birth & Sex ratio of offspring at hatching & $1: 1$ \\
\hline Density dependence of reproduction & $\begin{array}{l}\text { The relationship between reproduction and popula- } \\
\text { tion density }\end{array}$ & Yes \\
\hline$P(0)$ & $\%$ adult females breeding at low density & 35.70\% (Additional file 1: Table S1) \\
\hline$P(K)$ & $\%$ adult females breeding at carrying capacity & $50.00 \%$ (estimates) \\
\hline A & Allee parameter & 0 (Chen 2018) \\
\hline$B$ & Steepness parameter & 2 (Ralls et al. 1988) \\
\hline Proportion of adult females breeding & The percentage of adult females that breed each year & $\left(35.7-\left((35.7-50) \times\left((N / K)^{2}\right)\right)\right) \times(N /(0+N))$ \\
\hline EV in \% breeding & EV in \% of adult females breeding each year & $10 \%$ set as default \\
\hline Distribution of \# of offspring/female & $\begin{array}{l}\text { Statistical distribution characterizing the \# of offspring } \\
\text { produced }\end{array}$ & Specify exact distribution \\
\hline $\begin{array}{l}\text { 1. Offspring } \\
\text { 2. Offspring } \\
\text { 3. Offspring } \\
\text { 4. Offspring } \\
\text { 5. Offspring }\end{array}$ & $\begin{array}{l}\text { Percentages of females with certain numbers of } \\
\text { offspring }\end{array}$ & $\begin{array}{l}1.25 \% \\
10.00 \% \\
32.50 \% \\
53.75 \% \\
2.50 \% \text { (Additional file 1: Table S2) }\end{array}$ \\
\hline Female mortality & $\begin{array}{l}\text { Mortality rates of females, specified for three age } \\
\text { classes }(0-1,1-2, \text { and } 2+) \text { by the mean and SD }\end{array}$ & $\begin{array}{l}\text { For baseline: } 0-1,45.1 \% ; 1-2,15.1 \% ; 2+, 5.9 \% \text { (Wang } \\
2015 \text { ); SD set at } 10 \% \text { of the mean as default }\end{array}$ \\
\hline Male mortality & $\begin{array}{l}\text { Mortality rates of males, specified for three age classes } \\
(0-1,1-2 \text {, and } 2+) \text { by the mean and SD }\end{array}$ & Identical to female mortality \\
\hline Number of catastrophes & $\begin{array}{l}\text { Each type of catastrophe is implemented separately } \\
\text { and occurs independently }\end{array}$ & 2 \\
\hline Catastrophe frequency & Frequency of catastrophes affecting the population & $\begin{array}{l}\text { Catastrophe 1: } 14 \% \\
\text { Catastrophe } 2: 15 \%\end{array}$ \\
\hline Catastrophe severity & $\begin{array}{l}\text { Reduction in survivorship/reproduction as a result of } \\
\text { the catastrophe }\end{array}$ & $\begin{array}{l}\text { Catastrophe } 1 \text { : reduction in survivorship/reproduc- } \\
\text { tion: } 0.1 / 0.1 \\
\text { Catastrophe } 2 \text { : reduction in survivorship/reproduc- } \\
\text { tion: } 0.1 / 0.1\end{array}$ \\
\hline Mate monopolization & $\%$ of adult males breeding/year & 28.11\% (Additional file 1:Table S1) \\
\hline Initial population size & $\begin{array}{l}\text { The number of individuals at the beginning of the } \\
\text { simulation }\end{array}$ & 150 (population size in 2018) \\
\hline Age distribution of initial population & $\begin{array}{l}\text { Distribution of individuals by age at the beginning of } \\
\text { the simulation }\end{array}$ & Stable age distribution \\
\hline Carrying capacity & The carrying capacity of the environment & 420 (estimates) \\
\hline Harvest & $\begin{array}{l}\text { Whether individuals were removed from the popula- } \\
\text { tion }\end{array}$ & No harvest \\
\hline Supplementation & Whether individuals were added to the population & No supplementation \\
\hline
\end{tabular}

\#: number; EV: environmental variability 
environment capacity at present, with the nesting density in the core range of 0.73 nests $/ \mathrm{km}^{2}$ (Wang et al. 2020), namely average home-range size for each breeding pair was approximately $1.37 \mathrm{~km}^{2}$ in the wild population. The home-range size was restricted by the food, space, and other habitat environmental factors. Yangxian County can provide sufficient food resources for the Crested Ibis through dense water systems, paddy fields, and diverse vegetation cover types. However, the breeding and foraging grounds used by ibises in our focal population are located in intermontane basins that are often developed for use as paddy fields and interspersed with hills (Yu et al. 2015). The food abundance and availability of the Crested Ibis in Ningshan County is lower than that of Yang County. According to the average home-range size of the wild population and the difference of food resources between the two habitats, the home-range size of Crested Ibis in the study area is bigger than that in Yang County. Therefore, we estimated the average territory area of a breeding pair is estimated to be $2 \mathrm{~km}^{2}$. The average number of fledgelings per nest is roughly estimated to be 3 . Thus, we estimated the carrying capacity $(K)$ of Ningshan County to be $420 \pm 80$ individuals, including 84 breeding pairs, with approximately three young birds fledged per nest.

\section{Results}

In our simulation, the reintroduced ibis population is unlikely to go extinct but exhibits a stead growing trend within the next 50 years. Under current natural conditions, the intrinsic rate of increase $(r)$ of the population was estimated to be 0.084 with an SD $(r)$ of 0.071 . The number of individuals will increase to 367 , and the genetic diversity of the population will drop to 0.97 by the end of the next 50 years.

The sensitivity index $\left(S_{x}\right)$ of the population clearly showed that carrying capacity, sex ratio, frequency of catastrophes, and mortality were the four factors accounting for the population parameters (Table 2).

The carrying capacity and sex ratio have great effects on population size and extinction probability. If the carrying capacity was set to double or halve the current carrying capacity, the simulation results showed that the carrying capacity is the main factor restricting the population size. The smaller the carrying capacity hold, the shorter the duration required for the population to reach the $K$ value (Fig. $1 \mathrm{a}-\mathrm{c}$ ). The carrying capacity also affects the genetic diversity of the population. When the carrying capacity is reduced to half of the baseline value, the genetic diversity of the population is significantly different from that of the initial population (one-way ANOVA: $F_{2,147}=28.614, P<0.05$ ) (Fig. 2). We set six conditions of sex ratio imbalance to simulate population dynamics, and the results showed that if the sex ratio becomes extreme

Table 2 Results of different model parameters during the next 50 years and sensitivity analysis

\begin{tabular}{|c|c|c|c|c|}
\hline Description & Growth rate $(r \pm S D)$ & $\begin{array}{l}\text { Extinction probability } \\
(\%)\end{array}$ & Final population size & Sensitivity index $\left(S_{x}\right)$ \\
\hline Present conditions & $0.084 \pm 0.071$ & 0 & 367 & - \\
\hline$K=840$ & $0.083 \pm 0.069$ & 0 & 724 & 0.9728 \\
\hline$K=210$ & $0.081 \pm 0.080$ & 0 & 178 & 1.0300 \\
\hline Females:males $=1: 2$ & $0.085 \pm 0.091$ & 0 & 353 & -0.1142 \\
\hline Females:males $=2: 1$ & $0.024 \pm 0.071$ & 0 & 286 & 0.6608 \\
\hline Females:males = 1:3 & $0.034 \pm 0.092$ & 0 & 286 & -0.4414 \\
\hline Females:males $=3: 1$ & $-0.017 \pm 0.085$ & 1 & 82 & 1.5531 \\
\hline Females:males $=1: 4$ & $-0.012 \pm 0.098$ & 6 & 114 & -1.1490 \\
\hline Females:males $=4: 1$ & $-0.037 \pm 0.098$ & 13 & 28 & 1.5395 \\
\hline $10 \%$ higher frequency of catastrophes & $0.080 \pm 0.073$ & 0 & 358 & -0.2452 \\
\hline $10 \%$ lower frequency of catastrophes & $0.087 \pm 0.070$ & 0 & 362 & 0.1362 \\
\hline $50 \%$ higher frequency of catastrophes & $0.066 \pm 0.081$ & 0 & 350 & -0.0926 \\
\hline $50 \%$ lower frequency of catastrophes & $0.100 \pm 0.061$ & 0 & 371 & -0.0218 \\
\hline 10\% higher adult mortality & $0.081 \pm 0.073$ & 0 & 362 & -0.1362 \\
\hline 10\% lower adult mortality & $0.088 \pm 0.071$ & 0 & 363 & 0.1090 \\
\hline $10 \%$ higher subadult mortality & $0.081 \pm 0.072$ & 0 & 362 & -0.1362 \\
\hline 10\% lower subadult mortality & $0.086 \pm 0.071$ & 0 & 361 & 0.1635 \\
\hline 10\% higher fledgling mortality & $0.069 \pm 0.073$ & 0 & 352 & -0.4087 \\
\hline 10\% lower fledgling mortality & $0.096 \pm 0.072$ & 0 & 370 & -0.0817 \\
\hline
\end{tabular}




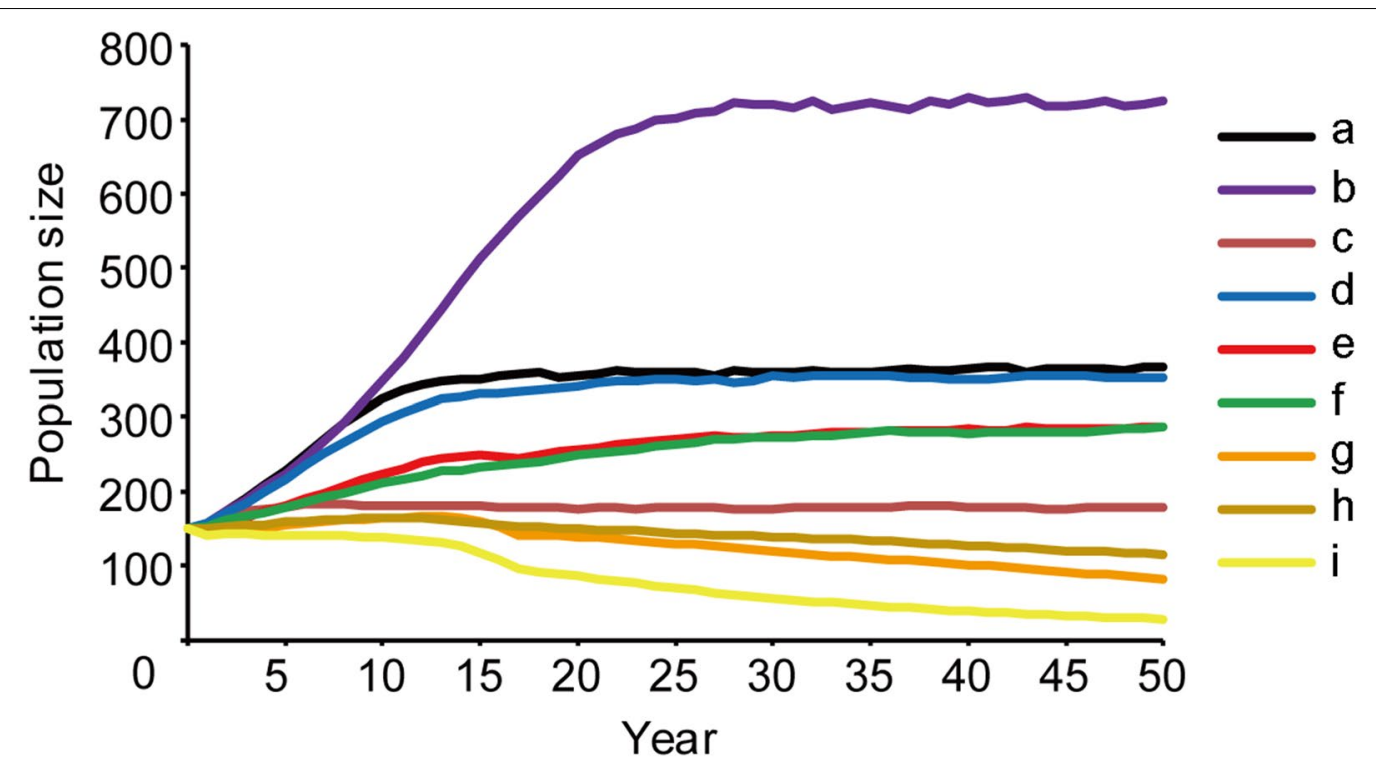

Fig. 1 Impact of different model parameters on the reintroduced population size. The data graph shows a present conditions, $\mathbf{b} K=840$, (c) $K=210, \mathbf{d}$ females:males $=1: 2, \mathbf{e}$ females:males $=2: 1, \mathbf{f}$ females:males $=1: 3, \mathbf{g}$ females:males $=3: 1, \mathbf{h}$ females:males $=1: 4$, and $\mathbf{i}$ females:males $=4: 1$

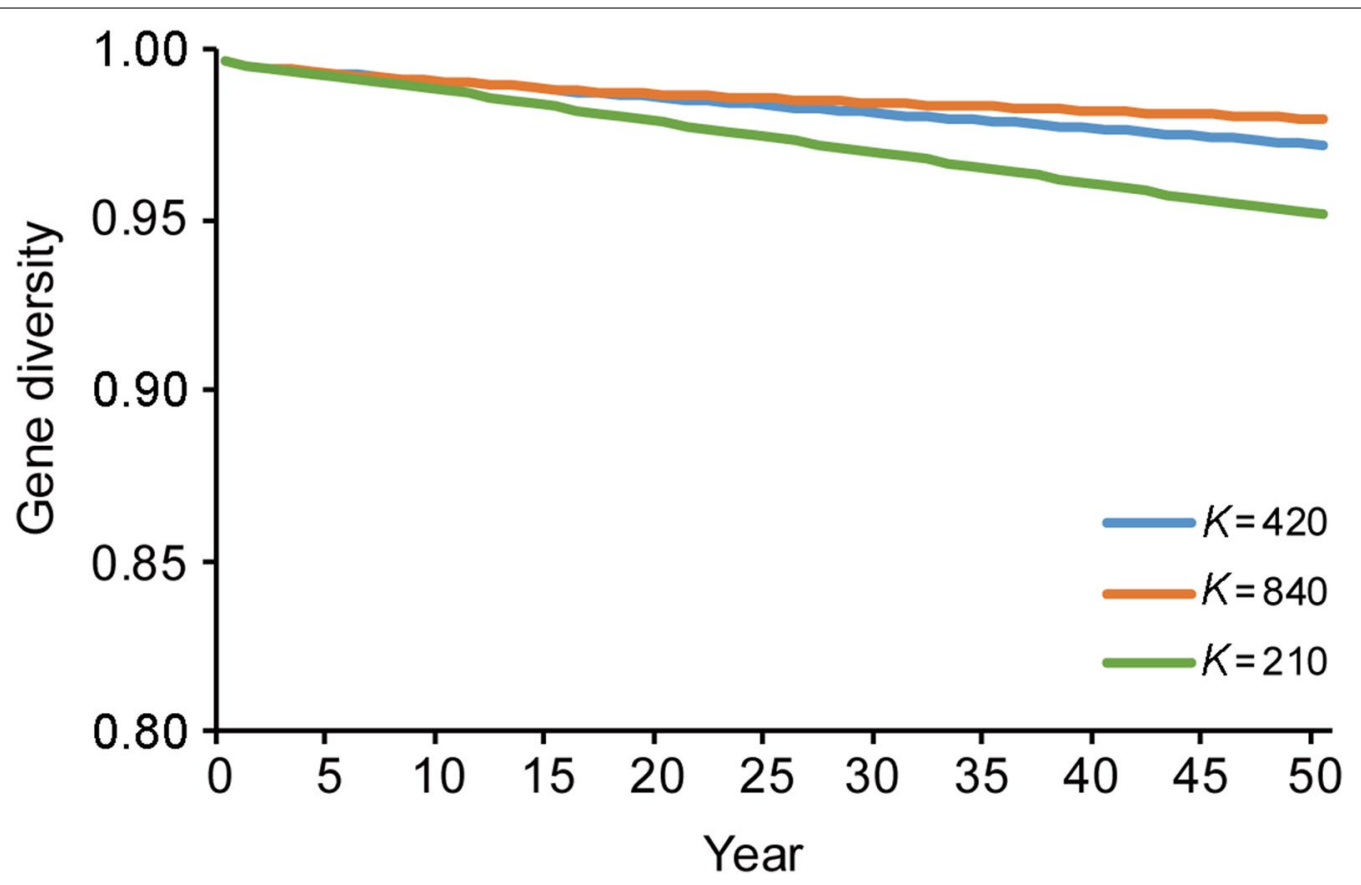

Fig. 2 Impact of carrying capacity on genetic diversity during the next 50 years. Three scenarios are imagined: the carrying capacity is 420 (blue), 840 (orange), and 210 (green), respectively

imbalanced, the population size will increase slowly over the next 50 years or even decline to the brink of extinction (Table 2, Fig. 1d-i). When the sex ratio has shifted to females or males to the same degree (such as $25 \%$ male vs. $75 \%$ male), the population shows an opposite growth trend (Table 2, Fig. 1f, g).
The results showed that although the frequency of catastrophes will not have a significant impact on population size, it will prevent the population from reaching the carrying capacity. That is the higher the frequency of catastrophes, the longer the population takes to reach the expected $K$ value (Fig. 3). Sensitivity analysis of mortality 


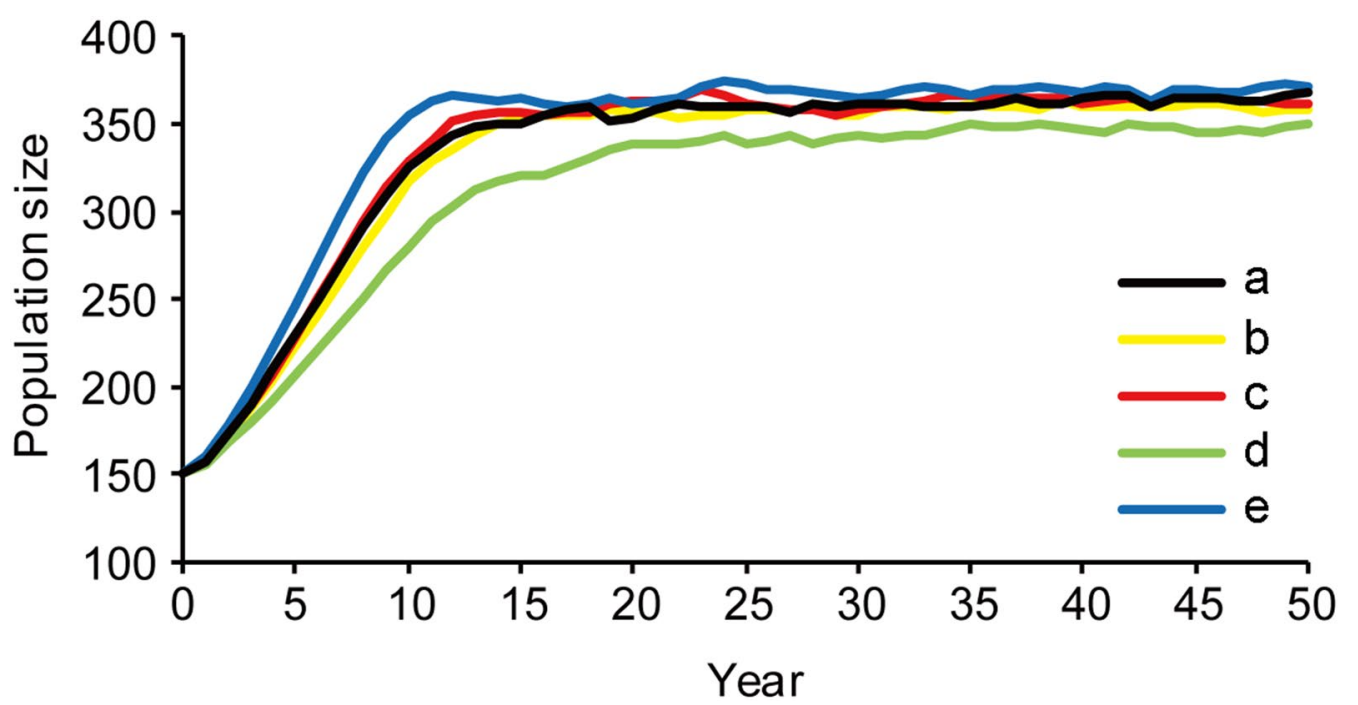

Fig. 3 Impact of different catastrophe frequencies on the population size. The data graph shows a baseline value of frequency of catastrophes, b frequency of catastrophes increased by $10 \%$, c frequency of catastrophes decreased by $10 \%$, d frequency of catastrophes increased by $50 \%$, e frequency of catastrophes decreased by $50 \%$

rates for each age class showed that changes in infant mortality had a greater impact on future population growth than changes in other age groups (Table 2).

\section{Discussion}

Since the release of 56 captive-reared Crested Ibises in 2007, long-term monitoring has been conducted to collect various types of field data. However, it is difficult to exactly quantify the mortality and a total number of individuals due to the large range of individual activities. In addition, we estimated the current population size to be approximately half of the carrying capacity. As a result, the parameters in the model, such as $K$ and $P(K)$, need to be roughly estimated. In conclusion, a certain amount of bias in simulation results may be produced because of insufficient field data.

According to the simulation results of the PVA model, the population size will constantly increase in the next 20 years, which means that the population will have reached the maximum carrying capacity. The population is resistant to slight fluctuations of catastrophe frequency, mortality, and sex ratio, indicating that it can also become a self-sustaining population without further releases. Despite being consistent with the results of population sustainability analysis, the population growth rate may still be affected by the following factors.

\section{Impact of inbreeding depression}

Inbreeding depression, commonly occurred in small populations, may lead to the decrease of population genetic diversity by increasing the frequency of homozygosity of harmful alleles. As a result, the reduced adaptability of offspring is likely to increase the risk of population extinction (Ellstrand and Elam 1993; Fischer et al. 2003).

However, under current circumstances, some studies indicated that the Crested Ibis has evolved a series of mechanisms to avoid inbreeding, such as dispersal and kin recognition (Macdonald and Johnson 2001; Liu and Zhang 2008). Besides, genetic diversity in small populations is also affected by genetic drift that can reduce the frequency of harmful genes (Bortoluzzi et al. 2020). Based on the current study and population status, we set the model parameters-lethal gene equivalent to zero in the present study. Therefore, the predicted population size might slightly overestimate the actual status of the population in the future. Combination of genetic diversity study with PVA should be made to estimate the exact lethal gene equivalent by investigating the relationship between observed heterozygosity and inbreeding coefficient, allowing more accurate prediction of the future dynamics for the ibis populations.

\section{Impact of carrying capacity}

In the sensitivity analysis, the higher sensitivity index occurs when the carrying capacity changes (Table 2), indicating that the carrying capacity has a great impact on the population size. From the results, we inferred there is a great potential for an expansion of the population, when the carrying capacity of the Crested Ibis is great. So carrying capacity is one of the primary factors restricting population size. The genetic diversity of the population can also be influenced by the carrying 
capacity because the mutation rate of small populations is much lower than its loss rate (Lande and Barrowclough 1987). When the mutation rate and loss rate of one population are at the same level under a certain scale of population size, the population can be adaptive to the change of environment and survive for a long time (Fan and Jiang 2007). Therefore, increasing the carrying capacity can increase the genetic heterozygosity of a population, which is beneficial to the long-term population growth.

Because of different emphases of the spatial carrying capacity and nutrient carrying capacity, the estimation results may vary to a great extent (Mentis and Duke 1976; Wallmo et al. 1977; Hobbs et al. 1982). For example, when estimating carrying capacity from the perspective of territory area, habitat fragmentation should be taken into account (Haila 2002; Wu and Li 2003). Carrying capacity may become smaller with the increase of habitat fragmentation, thus much attention should be paid to the edge effect caused by habitat fragmentation (Tallmon and Mills 2004). As for the present study, the carrying capacity of our focal population still remains unclear. Hence, more accurate estimation on the carrying capacity of the ibis population can be achieved by constructing the mathematical models under varied landscape scale in combined with individual nutrient requirements and habitat nutrient supply.

\section{Effect of sex ratio}

At present, the age structure of the Crested Ibis population in Ningshan County seems to be reasonable, with the sex ratio roughly at 1:1 (Li et al. 2018). The sensitivity analysis showed that the population size is highly sensitive to the sex ratio, which means that a certain degree of sex ratio deviation will exert a great impact on the subsequent fate of the population.

There is a varied impact of the sex ratio on population size of the current and wild population (Li 2013). A sex ratio imbalance of the same proportion (such as $25 \%$ male) will lead to a decline in the natality of Ningshan ibis population and then population extinction. However, the size of wild population in Yang County will only increase slowly, which may be due to the fact that the current population size of Ningshan County is much smaller than that of Yang County. Our results also showed that when the population sex ratio skews to males or females to the same extent (such as $25 \%$ male vs. $75 \%$ male), the population exhibits the opposite trend of increase or extinction, respectively. Under the influence of model parameter "mating monopoly", when there are fewer males in the population, the mating probability of the adult males is higher than that of the original model parameters, which may lead to an underestimation of simulation.

\section{Conservation and management recommendations}

Despite the initial successful reintroductions of the Crested Ibis in China, no predictive framework is available to quantify which general plan is vital to the recovery of the Crested Ibis within their former range. The present population is considered to be at the persistence stage, but threats at the population and metapopulation level remain. Some conservation management strategies that need to be addressed are listed as follows.

Nature reserves should be established to improve habitat quality in order to increase the carrying capacity. Additionally, local farmers should be encouraged to cultivate larger areas of paddy fields to ensure adequate food supply for the Crested Ibis. At the metapopulation level, habitat restoration and expansion are pressing issues for facilitating dispersal to promote individual exchanges between the wild and reintroduced populations. Priority should be given to determining the effects of predators on population dynamics and unknown reasons for individual mortality. Laws and regulations associated with management should be publicized, and punishment for illegal activities should be strictly enforced. Public education should be implemented to raise awareness of wildlife conservation.

\section{Supplementary Information}

The online version contains supplementary material available at https://doi. org/10.1186/s40657-021-00250-z.

Additional file 1: Table S1. The number of adult females and males that bred from 2008 to 2018. Table S2. Clutch size of Crested Ibis from 2008 to 2018.

\section{Acknowledgements}

We thank the staff of the Reintroduction Base of Crested Ibis in Ningshan County for providing logistical help and research aid. And special thanks to Robert Lacy and the IUCN/SSC for providing us the software for the VORTEX model.

\section{Authors' contributions}

$Y Z$ and $M L$ conceived and designed the study. $Y Z, F W, M L$ and $X L$ conducted the field work. $Y Z$ and FW carried out the analyses. $Y Z$ prepared the draft of the manuscript ZC, XYu and XYe revised it. All authors read and approved the final manuscript.

\section{Funding}

The study was supported by Shaanxi Forestry Bureau and National Natural Science Foundation of China (Grant Nos. 31872245 and 31572282).

\section{Availability of data and materials}

The datasets used in the present study are available from the corresponding author on reasonable request.

\section{Declarations}

Ethics approval and consent to participate Not applicable. 


\section{Consent for publication}

Not applicable.

\section{Competing interests}

The authors declare that they have no competing interests.

\author{
Author details \\ ${ }^{1}$ College of Life Sciences, Shaanxi Normal University, Xi'an 710119, China. \\ ${ }^{2}$ Reintroduction Center of Crested Ibis, Ningshan County, An'kang 725000 \\ China.
}

Received: 11 November 2020 Accepted: 25 March 2021

Published online: 09 April 2021

\section{References}

Akcakaya HR, Sjögren-Gulve P. Population viability analyses in conservation planning: an overview. Ecol Bull. 2000;48:9-21.

Archibald GW, Lantis SDH, Lantis LR, Munetchika I. Endangered ibises, Threskiornithinae: their future in the wild and in captivity. Int Zoo Yearb. 1980;20:6-17.

Armstrong DP, Seddon PJ. Directions in reintroduction biology. Trends Ecol Evol. 2008:23:20-5.

Blazquez M, Baker I, O'brien JM, Berrow SD. Population viability analysis and comparison of two monitoring strategies for Bottlenose Dolphins (Tursiops truncatus) in the Shannon Estuary, Ireland, to inform management Aquat Mamm. 2020;46:307-25.

Bortoluzzi C, Bosse M, Derks MFL, Crooijmans RPMA, Groenen MAM, Megens HJ. The type of bottleneck matters: insights into the deleterious variation landscape of small managed populations. Evol Appl. 2020;13:330-41.

Brook BW, O'grady JJ, Chapman AP, Burgman MA, Akçakaya HR, Frankham R. Predictive accuracy of population viability analysis in conservation biology. Nature. 2000;404:385-7

Brook CE, Herrera JP, Borgerson C, Fuller EC, Andriamahazoarivosoa P, Rasolofoniaina BJR, et al. Population viability and harvest sustainability for Madagascar lemurs. Conserv Biol. 2019;33:99-111.

Bustamante J. Population viability analysis of captive and released Bearded Vulture populations. Conserv Biol. 1996;10:822-31.

Byers DL, Waller DM. Do plant populations purge their genetic load? Effects of population size and mating history on inbreeding depression. Annu Rev Ecol Syst. 1999:30:479-513.

Chen JP. Allee effects based on night-roosting flock, individual survival, population growth for the reintroduced popuation of the Crested Ibis (Nipponia nippon) in Ningshan, Shaanxi Province, China. Master's Thesis. Shaanxi: Shaanxi Normal University; 2018 (in Chinese)

Dong R, Ye XP, Zhong L, Li X, Li M, Wang HQ, et al. Effects of breeding success, age and sex on breeding dispersal of a reintroduced population of the Crested Ibis (Nipponia nippon) in Ningshan County, China. Avian Res. 2018:9:314-20.

Ellstrand NC, Elam DR. Population genetic consequences of small population size: implications for plant conservation. Annu Rev Ecol Syst. 1993:24:217-42.

Fan PF, Jiang XL. Population viability analysis for Black Crested Gibbon (Nomascus concolor jingdongensis) in Dazhaizi at Mt. Wuliang, Yunnan, China. Acta Ecol Sin. 2007;27:620-6 (in Chinese).

Feng SH, Fang Q, Barnett R, Li C, Han SJ, Kuhlwilm M, et al. The genomic footprints of the fall and recovery of the Crested Ibis. Curr Biol. 2019;29:340-9.

Fischer M, Hock M, Paschke M. Low genetic variation reduces cross-compatibility and offspring fitness in populations of a narrow endemic plant with a self-incompatibility system. Conserv Genet. 2003;4:325-36.

Fryxell JM, Avgar T, Liu BY, Baker JA, Rodgers AR, Shuter J, et al. Anthropogenic disturbance and population viability of woodland caribou in Ontario. J Wildl Manag. 2020;84:636-50.

Fu CZ, Guang XM, Wan QH, Fang SG. Genome resequencing reveals congenital causes of embryo and nestling death in Crested Ibis (Nipponia nippon). Genom Biol Evol. 2019;11:2125-35

Haila Y. A conceptual genealogy of fragmentation research: from island biogeography to landscape ecology. Ecol Appl. 2002;12:321-34.

He CH, Du JJ, Zhu D, Zhang L. Population viability analysis of small population: a case study for Asian elephant in China. Integr Zool. 2020;15:350-62.
Henle K, Sarre S, Wiegand K. The role of density regulation in extinction processes and population viability analysis. Biodiver Conserv. 2004;13:9-52. Hernandez-Camacho CJ, Trites AW. Population viability analysis of Guadalupe fur seals Arctocephalus townsendi. Endanger Species Res. 2018;37:255-67.

Hobbs NT, Baker DL, Ellis JE, Swift DM, Green RA. Energy-and nitrogenbased estimates of elk winter-range carrying capacity. J Wildl Manag. 1982;46:12-21.

Huo ZP, Guo JF, Li X, Yu XP. Post-fledging dispersal and habitat use of a reintroduced population of the Crested lbis (Nipponia nippon). Avian Res. 2014;5:7.

IUCN/SSC. Guidelines for reintroductions. Gland: IUCN Species Survival Commission; 1998.

IUCN/SSC. Guidelines for reintroductions and other conservation translocations. Version 1.0. Gland: IUCN Species Survival Commission; 2013.

Keller LF, Waller DM. Inbreeding effects in wild populations. Trends Ecol Evol. 2002:17:230-41.

Kimanzi JK. Population viability analysis of the edangered roan antelope in ruma national park, kenya, and implications for management. Sci World J. 2018. https://doi.org/10.1155/2018/6015694.

King T, Chamberlan C, Courage A. Assessing reintroduction success in longlived primates through population viability analysis: western lowland gorillas Gorilla gorilla gorilla in Central Africa. Oryx. 2014;48:294-303.

Lacy RC. VORTEX: a computer simulation model for population viability analysis. Wildl Res. 1993;20:45-65.

Lande R, Barrowclough GF. Effective population size, genetic variation, and their use in population management. In: Soulé ME, editor. Viable populations for conservation. Cambridge: Cambridge University Press; 1987. p. 87-124.

Li HY. A population viability analysis for Nipponia nippon. Master's Thesis. Beijing: Beijing Forestry University; 2013 (in Chinese)

$\mathrm{Li} X \mathrm{H}$, Li DM. Current state and the future of the Crested Ibis (Nipponia nippon): a case study by population viability analysis. Ecol Res. 1998;13:323-33.

Li SB, Li B, Cheng C, Xiong ZJ, Liu QB, Lai JH, et al. Genomic signatures of nearextinction and rebirth of the Crested Ibis and other endangered bird species. Genom Biol. 2014;15:417-27.

Li YF, Ye XP, Wang M, Li X, Yu XP. Survival rates of a reintroduced population of the Crested Ibis Nipponia nippon in Ningshan County (Shaanxi, China). Bird Conserv Int. 2018;28:145-56.

Liu Y, Zhang ZW. Research progress in avian dispersal behavior. Front Biol. 2008:3:375-84.

Macdonald DW, Johnson DDP. Dispersal in theory and practice: consequences for conservation biology. In: Clobert J, Danchin E, Dhondt AA, Nichols JD, editors. Dispersal. Oxford: Oxford University Press; 2001. p. 358-72.

Mccarthy MA. Sensitivity analysis for models of population viability. Biol Conserv. 1995;73:93-100

Mentis RR, Duke MT. Carrying capacities of natural veld in Natal for large wild herbivores. S Afr J Wildl Res. 1976;6:65-74.

Miller PS, Lacy RC. VORTEX: a stochastic simulation of the extinction process. Version 9.5.0 user's manual. Apple Valley: Conservation Breeding Specialist Group (SSC/IUCN); 2005.

Milligan MC, Wells SL, Mcnew LB. A population viability analysis for Sharp-tailed Grouse to inform reintroductions. J Fish Wildl Manag. 2018:9.565-81.

Morris WF, Doak DF. Quantitative conservation biology: theory and practice of population viability analysis. Sunderland: Sinauer Associates; 2002.

Nagata $H$, Yamagishi S. Which factors affect post-release settlement of Crested Ibis Nipponia nippon on Sado Island, Japan? Ornithol Sci. 2016;15:181-9.

Perkins DW, Vickery PD, Shriver WG. Population viability analysis of the Florida Grasshopper Sparrow (Ammodramus Savannarum Floridanus): testing recovery goals and management options. Auk. 2008;125:167-77.

Ralls K, Ballou JD, Templeton A. Estimates of lethal equivalents and the cost of inbreeding in mammals. Conserv Biol. 1988;2:185-93.

Reed JM, Murphy DD, Brussard PF. Efficacy of population viability analysis. Wild Soc Bull. 1998;26:244-51.

Robert A, Colas B, Guigon I, Kerbiriou C, Mihoub JB, Saint Jalme M, et al. Defining reintroduction success using IUCN criteria for threatened species: a demographic assessment. Anim Conserv. 2015;18:397-406.

Song YL. Population viability analysis for two isolated populations of Haianan eld's deer. Conserv Biol. 1996;10:1467-72. 
Sung HC, Ryong PS, Cheong S. A population viability analysis (PVA) for re-introduction of the Oriental White Stork (Ciconia boyciana) in Korea. Korean J Environ Biol. 2012;30:307-13.

Tallmon DA, Mills LS. Edge effects and isolation: red-backed voles revisited. Conserv Biol. 2004;18:1658-64.

Wallmo OC, Carpenter LH, Regelin WL, Gill RB, Baker DL. Evaluation of deer habitat on a nutritional basis. J Range Manag. 1977;30:122-7.

Wang M. Outcome assessment of the reintrodution of the Crested Ibis ( Nipponia nippon) implemented in Ningshan County, Shaanxi, China. Master's Thesis. Shaanxi: Shaanxi Normal University; 2015 (in Chinese).

Wang M, Ye XP, Li YF, Huo ZP, Li X, Yu XP. On the sustainability of a reintroduced Crested Ibis population in Qinling Mountains, Shaanxi, Central China. Restor Ecol. 2017;25:261-8.

Wang C, Zhang YZ, Zeng JW, Gao J, Yan L, Liu DP. Reproductive status and population size of wild Crested Ibis (Nipponia nippon) in China. Sci Silvae Sin. 2020;56:143-50 (in Chinese).

Wei D. Habitat suitability evaluation of reintroduced Crested Ibis from Shaanxi province. Master's Thesis. Shaanxi: Shaanxi Normal University; 2020 (in Chinese)

Wu ZJ, Li YM. Effects of habitat fragmentation on survival of animal populations. Acta Ecol Sin. 2003;23:2424-35 (in Chinese)
Yoon HJ, Choi JY. A study on the proper selection of ecological habitat for the wild radiation of Crested Ibis (Nipponia nippon). IOP Conf Ser Earth Environ Sci. 2018. https://doi.org/10.1088/1755-1315/151/1/012011.

Yu XP, Lu BZ, Lu XR, Liu NF. Influences of age on the reproductive success of the Crested Ibis Nipponia nippon. Curr Zool. 2007;53:812-8 (in Chinese)

Yu XP, Chang XY, Li X, Chen WG, Shi L. Return of the Crested Ibis Nipponia nippon: a reintroduction programme in Shaanxi province, China. Bird Asia. 2009;11:80-2.

Yu XP, Li X, Huo ZP. Breeding ecology and success of a reintroduced population of the endangered Crested Ibis Nipponia nippon. Bird Conserv Int. 2015;25:207-19.

Zhai TQ, Wang ZY, Zhang HJ. The study on the reproduction of two ages Crested Ibis (Nipponia nippon). Acta Ecol Sin. 1994;14:99-101 (in

\section{Chinese).}

Zhai TQ, Lu XR, Lu BZ, Zhang YM, Wang JH. Nest building, egg laying, hatching, and breeding of Crested Ibis (Nipponia nippon). Curr Zool. 2001;47:508-11 (in Chinese).

Zhu LF, Deng C, Zhao X, Ding JJ, Huang HS, Zhu SL, et al. Endangered Père David's deer genome provides insights into population recovering. Evol Appl. 2018;11:2040-53.
Ready to submit your research? Choose BMC and benefit from:

- fast, convenient online submission

- thorough peer review by experienced researchers in your field

- rapid publication on acceptance

- support for research data, including large and complex data types

- gold Open Access which fosters wider collaboration and increased citations

- maximum visibility for your research: over 100M website views per year

At BMC, research is always in progress.

Learn more biomedcentral.com/submissions 